\title{
Badanie ankietowe jako element ewaluacji jakości kształcenia na uczelniach wyższych
}

\begin{abstract}
The paper concerns on advantages and disadvantages of survey researches used as tools in the process of evaluation of education quality in contemporary Poland. Education quality is usually surveyed by using questionnaires accessible in electronic internet form as a part of the USOS system. It is implied that survey, as a research method, is an effective means applicable to measure opinions, attitudes and expectations of the students. Moreover, the internet form of survey takes the most of advantages of the traditional forms of research, which makes it an efficient tool in the process of evaluation in the higher education. This way of research prevail at Polish universities.
\end{abstract}

\section{Key words:}

survey research, quality of education, higher education, USOS system

Reforma szkolnictwa wyższego, wprowadzana w Polsce na początku obecnego dziesięciolecia w uczelniach publicznych i niepublicznych, zakłada sformalizowanie w większym niż do tej pory stopniu procesu dydaktycznego, co wyraża się m.in. we wdrażaniu procedur związanych z dbałością o jakość kształcenia. Wysoka

1 Marek Jeziński, Katedra Dziennikarstwa i Komunikacji Społecznej, Wydział Politologii i Studiów Międzynarodowych, Uniwersytet Mikołaja Kopernika w Toruniu, Polska, jezmar@umk.pl. 
jakość oferty edukacyjnej, niejako zadekretowana ministerialnie, stała się swego rodzaju punktem dojścia, do którego dążyć mają uczelnie kształcące na studiach wyższych I, II i III stopnia. Jest to jedna z podstawowych sfer, w jakich projektowane i podejmowane są działania mające na celu sprostanie warunkom reformy.

Istotnym aspektem działań, o których mowa, jest cały szereg działań projakościowych zakładających ewaluację podjętych kroków, a więc ocena sposobu, w jaki reforma jest wdrażana na najniższych szczeblach - na wydziałach oraz poszczególnych kierunkach studiów. Służy temu ewaluacja efektów kształcenia przez odpowiednie instytucjonalne czynniki, profilowanie efektów kształcenia i programów studiów zgodnie z aktualnymi i prognozowanymi oczekiwaniami rynku pracy, udział interesariuszy zewnętrznych w procesie planowania efektów kształcenia i programów studiów oraz ocena jakości pracy dydaktycznej na wydziałach, a więc ocena nauczania przez poszczególnych pracowników prowadzących zajęcia dydaktyczne. Ta ostatnia kwestia jest na większości polskich uczelni publicznych badana za pomocą ankiet wypełnianych dobrowolnie przez studentów poszczególnych kierunków. Badania takie mają wieloletnią tradycję - funkcjonują nie tylko jako możliwość poznania opinii studentów o samych studiach i wykładowcach, ale są także istotnym elementem składowym okresowej oceny pracy każdego pracownika dydaktycznego i tradycyjnie odbywały się w formie drukowanej i powielanej ankiety papierowej. Po wprowadzeniu przez wiele polskich uczelni elektronicznych systemów obsługi studentów, najpopularniejszym z nich jest USOS - stosowany na wielu polskich uniwersytetach, badania te prowadzone są na ogół w formie elektronicznej ankiety dostępnej w formie aplikacji będącej częścią systemu.

Warto zastanowić się nad zaletami i wadami badania ankietowego online w kontekście wykorzystywania go przez polskie uniwersytety. Punktem wyjścia przyjętym w artykule będą metodologiczne pozytywy badania tego typu w środowisku tradycyjnym mające w Polsce wieloletnią tradycję naukową (por. m.in.: Lutyńska, 2000, 1993; Nowak, 1985; Sułek, 1990, 2002; Sztumski, 1995). Zakładam, że badania przy pomocy ankiet powielanych i dystrybuowanych w formie papierowej posiadają pewną dynamikę, która ulega przekształceniom wobec badań prowadzonych w środowisku nowych mediów. Metodologicznie rzecz ujmując, tradycyjne badania ankietowe muszą zostać uzupełnione o określone charakterystyki w kontekście prowadzenia badań online. Do tego ostatniego typu procedur badawczych odnosić się będą zasadnicze uwagi proponowane w niniejszym szkicu. Przykłady z badań ankietowych online ilustrujące wywód pochodzą głównie z kwestionariuszy zaproponowanych studentom Uniwersytetu Mikołaja Kopernika w Toruniu. Uwagi metodologiczne sformułowane w pracy wynikają 
z analiz ankiet oraz ich wyników uzyskiwanych na podstawie kwestionariuszy wypełnianych przez studentów w Uczelnianym Systemie Obsługi Studentów (USOS) w latach 2011/2012 i 2012/2013. Dodajmy, że spostrzeżenia metodologiczne dotyczące ankiet studenckich konsultowane były przez autora niniejszego artykułu z pracownikami innych uniwersytetów w Polsce, takich jak: Uniwersytet Wrocławski, Uniwersytet Warszawski, Uniwersytet Śląski w Katowicach, Uniwersytet Marii Curie-Skłodowskiej w Lublinie, Uniwersytet Kazimierza Wielkiego w Bydgoszczy, Uniwersytet Warmińsko-Mazurski w Olsztynie. Z rozmów tych klarownie wynika, że sytuacja panująca na UMK wykazuje znaczące podobieństwo do warunków panujących na innych uczelniach wyższych.

\section{BADANIE ANKIETOWE I BADANIE ANKIETOWE ONLINE - POSTAWOWE PROBLEMY}

\subsection{BADANIA ANKIETOWE NA UCZELNI WYŻSZEJ - ZALETY}

Zauważmy na wstępie, że ocena pracy dydaktycznej pracowników naukowych uniwersytetów w formie ankietowej rozpowszechnianej za pomocą środowiska nowych mediów jest tematem odpowiednim do takiego rodzaju badania. Jednostką analizy są tu pojedynczy ludzie - studenci. Służą oni, jak zaznacza Earl Babbie, „jako respondenci lub informatorzy. (...) zbieramy dane w celu opisywania populacji zbyt dużej, by obserwować ją bezpośrednio (2003, s. 268)”. Badania takie są też „narzędziem pomiaru postaw i poglądów w dużej populacji (s. 268-269)”. Taka właśnie sytuacja występuje w omawianych w artykule badaniach online nad grupami studentów oceniających wykładowców: dotyczą one dużych populacji. O ile jednak w badaniach sondażowych do czynienia mamy na ogół z procedurą określania próby losowanej do badania (ambicją przeprowadzającego badanie jest zazwyczaj dobranie próby reprezentatywnej, pozwalającej na dokonanie daleko idących uogólnień wyników przebadanej próby na całą populację), o tyle w badaniach uniwersyteckich do czynienia mamy z próbą przebadania całej populacji. Co oczywiste, pożądana jest taka sytuacja, w której przebadamy całość populacji, a to będzie mieć miejsce tylko wtedy, kiedy wszyscy studenci zarejestrowani w danym semestrze w systemie USOS jako studenci rzetelnie wypełnią ankietę. Jest to jednak, ze zrozumiałych względów, przykład sytuacji społecznie, dydaktycznie i metodologicznie pożądanej, acz nie do końca możliwej do spełnienia - ankiety wypełniane są na zasadzie dobrowolności i anonimowości, co oznacza, że nie istnieją formalno-instytucjonalne sposoby nakłaniania studentów do wypełnienia 
kwestionariusza. Można ich jedynie zachęcać do wzięcia udziału w badaniu, ewentualnie wskazując pewne psychologiczne gratyfikacje takiej sytuacji (umacnianie więzi z uczelnią, tworzenie specyficznej wspólnoty akademickiej, czy choćby kreowanie poczucia „my” w odniesieniu do całości danego uniwersytetu). Jak pokazują wyniki ankiet, pod względem liczby osób biorących udział w takich badaniach wskazane wyżej czynniki motywujące nie są skutecznym elementem mobilizującym studentów do czynnego brania udziału w badaniu, mimo że czas mu poświęcany nie jest długi - ankiety liczą na ogół kilkanaście pytań i wypełnienie ich nie wymaga zaangażowania znaczących zasobów energetycznych ani intelektualnych ze strony respondenta.

Badanie za pomocą kwestionariusza ankiety, używane w badaniu ewaluacyjnym, o którym mowa, ma kilka istotnych zalet, ale też i minusów - warto poświęcić im kilka słów komentarza. Do grupy tych pierwszych należą:

- łatwość badania na dużych grupach respondentów;

- możliwość przeprowadzenia pilotażu;

- możliwość zaprojektowania procedur triangulacyjnych na podstawie wyników badania ankietowego;

- możliwość zapewnienia badanemu anonimowości i poufności;

- znany respondentowi sposób badania;

- niski koszt badania.

Zrozumiałe jest, że zbadanie kilku-, kilkunasto- czy nawet kilkudziesięciotysięcznej populacji, którą stanowią studenci uniwersytetu, wymaga narzędzia, z którym skutecznie można dotrzeć do odbiorcy. To zbyt duża grupa, by stosować inne metody i techniki badania, choć - z naturalnych względów - mogą być one wykorzystane w planowaniu procedur triangulacyjnych (grupa fokusowa, pogłębione wywiady swobodne z wybranymi przedstawicielami studentów, profilowane ankiety szczegółowe dotyczące specyficznych tematów, najczęściej związanych z określonym kierunkiem studiów). Ankieta zintegrowana z systemem USOS jako funkcjonalna aplikacja spełnia te warunki. Podobnie jest z wymienionymi wyżej kolejnymi kwestiami - możliwością przeprowadzenia pilotażu, korygowania błędów kwestionariusza i innymi formami ulepszania procedur badawczych. Założyć można, że są one w relatywnie łatwy sposób osiągalne w badaniach uczelnianych jako procedury projakościowe.

Nie występuje także w badaniu online problem zwrotów - ankiety tych, którzy decydują się na takie badanie, zwracane są automatycznie. Kwestia ta wiąże się jednak bezpośrednio z problemem liczby osób biorących udział w takim badaniu, na co przyjdzie zwrócić uwagę w dalszej części tej pracy (por. Sobieszek, 2006; 
Szpunar, 2008, s. 42-54; Szreder, 2010, s. 106; Zając, 2006; Zając, Batorski, 2007, s. 234-247).

Badanie takie jest ponadto popularne i przez to - znane większości (lub niemal wszystkim) respondentów z różnorodnych kontekstów społecznych. Wyniki różnorodnych badań ankietowych publikowane są często w mediach, co ma miejsce choćby przy okazji wyborów odbywanych na scenie politycznej, kiedy to media z relatywnie dużą częstotliwością upubliczniają aktualne wyniki badań, na które powołują się politycy i komentatorzy. Badania takie stosowane są także często na uczelniach - studenci biorą w nich udział przy różnych okazjach, zazwyczaj odpowiadając na ankiety podczas każdego semestru studiów. Oznacza to, że forma badania ankietowego jest dobrze zakorzeniona w świadomości respondentów, rozpoznawalna we właściwy sposób i na ogół nie wymaga ona złożonych procedur informacyjnych poprzedzających samo badanie. Traktowane jest ono jako oczywisty element procesu dydaktycznego - ankiety oceniające są przeprowadzane jako część rutynowej pracy każdej niemal uczelni. Co więcej, łatwość wypełniania samej ankiety sprawia (pytania powinny być wszak komunikatywne - i ten warunek na ogół jest spełniany w kwestionariuszach używanych na polskich uniwersytetach), że można badanie tego typu przeprowadzić szybko i bezstresowo, a wskazana wyżej znajomość formy badania ankietowego sprzyja dodatkowo łatwości procedury badawczej.

\subsection{BADANIA ANKIETOWE ONLINE}

Wymienione tu zalety badania ankietowego prowadzonego przez USOS zbieżne są, jak można zauważyć, z zaletami badań ankietowych wymienianych w teorii badań społecznych. Z metodologicznego punktu widzenia natomiast najistotniejszymi kwestiami pozostają w analizowanym tu kontekście problematyka prowadzenia badań w środowisku online i różnice, jakie występują w procedurach online i offline. W przypadku badania na studentach wskażmy przede wszystkim te zalety prowadzenia badań online, które są niejako uzupełniniem aspektów badań znanych już z procedur badawczych prowadzonych w formie ankiet tradycyjnych (drukowanych na papierze i powielanych). Wskażmy i opatrzmy komentarzem te dodatkowe zalety:

- łatwość dotarcia do adresata ankiety;

- łatwość wypełniania kwestionariusza;

- łatwość korygowania błędów kwestionariusza;

- brak barier związanych ze zwrotem ankiet;

- nieograniczona dostępność kwestionariusza; 
- możliwość uniknięcia efektu ankietera;

- niemal zerowy koszt badania.

Ankieta online dociera do studenta bezpośrednio przez system USOS - jest ona aplikacją, która pojawia się przy każdym przedmiocie, na który student zarejestrował się elektronicznie na początku danego semestru studiów. Kwestionariusz zawiera zazwyczaj pytania zamknięte - odznaczane „kliknięciami” komputerowej myszki w okienka możliwych odpowiedzi na pytania, zdefiniowanych przez twórców ankiety. Oznacza to, że kwestionariusz można łatwo znaleźć w systemie, zrozumieć jego założenia, wypełnić szybko i w zasadzie bezstresowo. Jedynym problemem pozostaje zachęcenie studenta do przyjęcia roli respondenta w badaniu. Jak zauważa Babbie (2003, s. 273): „respondenci muszą chcieć odpowiadać. Często chcemy dowiedzieć się czegoś od osób, które nie są chętne, by się tym z nami dzielić”. Powody takich sytuacji mogą być, co zrozumiałe, różne, jednak w przypadku grupy respondentów, jakimi są studenci, mówić można o braku motywacji do wzięcia udziału w badaniu i braku stosownej gratyfikacji z badaniem związanej, o czym w kolejnym podpunkcie niniejszego artykułu.

Ponadto badania online cechuje niegraniczona dostępność kwestionariusza pod względem czasowym i przestrzennym. Oznacza to, że respondent może go wypełnić wtedy, kiedy sam się na to zdecyduje - do czynienia mamy tu z dowolnością ograniczaną jedynie dostępnością odpowiednich technologii w danym miejscu i czasie. Jest zatem niezależny od fizycznego kontaktu z ankieterem, czyli unika stresu związanego z wizytą w domu, niechcianymi telefonami, nagabywaniem w miejscach publicznych itp. Ma to istotne znaczenie dla dynamiki badania, bowiem istnieje szansa na bezstresowe odbycie całej procedury, co ma przełożenie na emocje, które mogą pojawić się w związku z kontaktem z nieznanym respondentowi człowiekiem, jakim zazwyczaj jest ankieter czy badacz. Zaznaczmy od razu, że kwestia nieograniczonej dostępności może stanowić także czynnik negatywnie obciążający badanie - jeśli respondent może dokonać wypełnienia ankiety kiedykolwiek, to znaczy to, że bez dodatkowych sposobów motywowania go do wypełnienia ankiety może tego w ogóle nie dokonać.

Niebagatelną w tym kontekście kwestią jest problem kosztów badania - ankiety w tradycyjnej formie były powielane na kserokopiarkach i rozdawane studentom podczas ostatnich zajęć w semestrze (taka forma była powszechna jeszcze w połowie ubiegłego dziesięciolecia), co generowało określone koszty - zużycie tonera, urządzeń, papieru, a nie wpływało w substancjalny sposób na jakość samego badania. Badania takie projektowane były i zazwyczaj nadal są przez pracowników etatowych danej uczelni (zajmujących się metodologią badań w wymiarze 
socjologicznym, politologicznym, ekonomicznym, pedagogicznym - dostępność zasobów ludzkich w tym sektorze jest na ogół powszechna w państwowych placówkach edukacyjnych), bez wynajmowania podmiotów zewnętrznych, co ma zadecydowany wpływ na koszt omawianych w szkicu procedur. Oznacza to, że formularz ankiety sporządzany jest w zasadzie bezkosztowo (przykładowo: ankiety przygotować można w ramach cyklicznych prac zespołu uczelnianej komisji dydaktycznej lub specjalistów desygnowanych przez władze szkoły wyższej) i w taki też sposób umieszczany w sieci internetowej przez obsługę uczelnianego centrum informatycznego (na uniwersytetach istnieją powoływane w tym celu jednostki ogólnouczelniane). Dotyczy to także procedur poprawiania ankiety odbywa się to taki sam sposób, jeżeli trzeba zmienić treści zawarte w pytaniach lub uzupełnić ich treść.

To samo dotyczy także etyki w badaniach online - anonimowość i poufność są w nich daleko posunięte, a efekt ankietera w zasadzie wyeliminowany. Można w związku z tym wręcz mówić o depersonifikacji badania - sytuacja badania nie niesie dla respondenta dodatkowego stresu związanego z kontaktem personalnym z ankieterem. Kontakt ankieter-respondent zastąpiony jest przez pośrednika, jakim jest komputer czy smartfon, na którym wypełnić można ankietę. To kwestia niebagatelna, bowiem niektóre pytania mogą być niewygodne dla studenta, który mógłby nie chcieć szczerze odpowiedzieć na pytanie dotyczące choćby własnej frekwencji na zajęciach.

Zauważmy, że sytuacja, o której mowa, związana w badaniach z kontaktem zapośredniczonym przez komputer jest jednym z najistotniejszych problemów, z jakimi spotykają się badacze w środowisku online. Robert Kozinets (2012, s. 104 i nast.) wyszczególnia cztery specyficzne cechy związane z tym problemem, są nimi: modyfikacja, anonimowość, dostępność i archiwizacja, z których najważniejsza jest ta pierwsza. Oznacza ona zmianę sposobu komunikowania się między ludźmi. W kontekście rozważań prowadzonych w niniejszym artykule oznacza ona zmianę natury jakościowej - w tradycyjnych badaniach to wykładowca zachęcał studentów do wypełnienia ankiety papierowej, rozdając im kwestionariusz, obecnie ankieta dystrybuowana jest w systemie USOS, co oznacza brak czynnika kontaktu z innym człowiekiem, a wykładowca może jedynie przypomnieć o istnieniu ankiet jako systemowej aplikacji. Dodajmy, że cechy środowiska nowomedialnego, na które wskazuje Kozinets, wynikają bezpośrednio z uwarunkowań społecznych i technologicznych, w jakim są prowadzone badania netnograficzne. 


\subsection{NEGATYWNE STRONY BADANIA ANKIETOWEGO ONLINE}

Badanie ankietowe online na uczelni wyższej, oprócz wskazanych powyżej zalet, ma pewne wady, związane z samą sytuacją badania. Przyjrzyjmy się najważniejszym z nich, mogącym mieć wpływ na jakość przeprowadzanego badania ankietowego:

- brak pogłębienia jakościowego w badaniu;

- mała liczba osób wypełniających kwestionariusz;

- depersonifikacja sytuacji badania;

- brak pewności, co do tożsamości wypełniającego ankietę;

- narzucenie badanemu określonej w kwestionariuszu wizji świata;

- narzucenie badanemu tematyki ściśle określonej przez badacza;

- fetyszyzacja badań ankietowych.

Warto przyjrzeć się owym negatywnym stronom badań, o których mowa. O ile pierwsza z nich nie wymaga zasadniczego komentarza, bowiem jest wadą badań ankietowych dobrze rozpoznaną przez metodologów. Jest to niejako symboliczny koszt, jaki ponosimy w badaniach dużych grup ludzkich - na tym zasadza się wszak badanie ilościowe. Próbą przezwyciężenia takiego minusa badań ankietowych jest odpowiednie zaprojektowanie procedur triangulacyjnych (wywiady, fokusy), jednak nie są one powszechnie stosowane na polskich uczelniach.

Kwestia druga, czyli niski poziom wypełniających kwestionariusz, jest najważniejszym problemem, jaki staje przed zarządzającymi jakością na polskich uczelniach. Ankiety są wypełniane przez studentów na zasadzie dobrowolności, co oznacza, że w badaniu biorą udział ci i tylko ci, którzy się na to świadomie decydują. To niewątpliwa zaleta takiej procedury, jednak jest ona jednocześnie dużym obciążeniem - na badanie decyduje się relatywnie niewielka liczba osób. Warto podać przykłady, by unaocznić skalę problemu. W tym celu posłużę się danymi ankiet przeprowadzonych po zakończeniu prowadzonych przeze mnie przedmiotów na Wydziale Politologii i Studiów Międzynarodowych UMK w latach 2011/2012 i 2012/2013 - przykłady pochodzą z kierunków studiów „politologia” (w tabeli poniżej oznaczone jako: P), „dziennikarstwo i komunikacja społeczna” (DiKS) oraz „bezpieczeństwo wewnętrzne” (BW), ankiety wypełniane zostały przez studentów trybów stacjonarnego i niestacjonarnego. Dane zestawiono w tabeli poniżej - liczby w kolumnach trzeciej i czwartej oznaczają liczbę studentów, którzy zarejestrowali się na dane zajęcia w USOS (a więc mieli prawo do wypełniania ankiety ewaluacyjnej przedmiotu), zaś w kolumnie ostatniej podano 
wyliczenie procentowe - stosunku zarejestrowanych do tych, którzy zdecydowali się na wypełnienie kwestionariusza².

Tabela 1. Dane ankiet przeprowadzonych na Wydziale Politologii i Studiów Międzynarodowych UMK w latach 2011/2012 i 2012/2013

\begin{tabular}{lllll}
\hline PRZEDMIOT & $\begin{array}{l}\text { Rok aka- } \\
\text { demicki }\end{array}$ & $\begin{array}{l}\text { Zare- } \\
\text { jestro- } \\
\text { wanych } \\
\text { w USOS }\end{array}$ & $\begin{array}{l}\text { Ankiet } \\
\text { wypełnio- } \\
\text { nych }\end{array}$ & Procent \\
\hline Socjologia ogólna (BW) & $2012 / 2013$ & 97 & 20 & 20.6 \\
\hline Socjologia (DiKS) & $2012 / 2013$ & 143 & 20 & 14 \\
\hline Nauka o komunikowaniu (DiKS) & $2012 / 2013$ & 22 & 4 & 18 \\
\hline Metody badań medioznawczych (DiKS) & $2012 / 2013$ & 103 & 14 & 13.5 \\
\hline Metody i techniki badań (DiKS) & $2012 / 2013$ & 98 & 9 & 9.1 \\
\hline Metody i techniki badań (DiKS) & $2011 / 2012$ & 78 & 14 & 18 \\
\hline Metody i techniki badawcze (P) & $2011 / 2012$ & 98 & 28 & 28.5 \\
\hline Socjologia (DiKS) & $2011 / 2012$ & 112 & 6 & 5.3 \\
\hline
\end{tabular}

Źródło: Opracowanie własne.

W rozważaniach dotyczących zalet badania ankietowego wymieniono kontakt zapośredniczony przez sieć www (komputer, smartfon) jako sytuację sprzyjającą badaniu, bowiem w ten sposób można wyeliminować efekt eksperymentatora/ ankietera. Zwróćmy jednak uwagę, że sytuacja bezpośredniego kontaktu pomiędzy badaczem a respondentem może w niektórych sytuacjach sprzyjać badaniu. Wydaje się, że częściowo mielibyśmy do czynienia z taką właśnie sytuacją w badaniach, o których mowa. Niski stopień zainteresowania ankietami wśród studentów uznać należy za negatywną stronę ewaluacji jakości kształcenia, a bezpośrednia prośba wykładowcy skierowana do studentów o wypełnienie ankiety sprzyjać musi zainteresowaniu badaniem. Niekoniecznie musi to oznaczać koszta związane z kopiowaniem ankiety - badanie można odbyć podczas zajęć w sali komputerowej wyposażonej w dostęp do systemu (co oczywiste - nie wszędzie mieć będziemy do czynienia z warunkami umożliwiającymi takie działanie).

Zauważmy w niniejszym kontekście, że autorytet pracownika akademickiego uznać należy w tej sytuacji za czynnik motywujący do wypełnienia ankiety brak tego elementu w sytuacji odpersonifikowanej, z jaką mamy do czynienia

2 Co zrozumiałe, dane przytoczone w pracy nie roszczą sobie prawa do kompletności. Kwestia niskiego poziomu zwrotów ankiet musi stać się przedmiotem osobnego badania. 
w przypadku zamieszczenia treści kwestionariusza w systemie USOS. Co więcej, zainteresowanie wykładowcy i skłanianie studentów do wypełniania ankiety działa nie tylko mobilizująco, lecz także uznać je należy za swego rodzaju formę psychologicznego docenienia, istotną dla większości indywidualnych studentów. Respondent zazwyczaj pragnie być doceniony, a wzięcie udziału w badaniu jest taką właśnie formą swoistej psychologicznej nagrody.

Kolejny problem, na który napotykamy przy realizacji kwestionariuszowych badań online i offline, to swego rodzaju narzucenie odbiorcy pewnej perspektywy przez badacza poprzez pytania w ankiecie. Każde pytanie i ich sekwencja to pewna perspektywa, która tworzy określoną narrację i związane z nią znaczenia - samo zamieszczenie tych, a nie innych pytań powoduje, że respondent skłonny jest uznać je za istotne dla danego problemu badawczego, nawet jeśli wcześniej nie interpretował ich w taki sposób. Podobnie jest z użyciem określonych słów w kwestionariuszu - one mogą mieć zabarwienie emocjonalne, na co zwraca się ze zrozumiałych względów - szczególną uwagę w metodologii badań społecznych i teorii badań ${ }^{3}$. W taki też sposób ma się kwestia niedookreśloności niektórych słów używanych w badaniach kwestionariuszowych. Mogą one być interpretowane przez wypełniającego ankietę w różny sposób, ludzie przypisywać im mogą różne zakresy znaczeniowe, co sprawia, że odpowiedzi różnych osób mogą być nieporównywalne i interpretowane w nieadekwatny sposób. Przykładowo w ankietach stosowanych na polskich uniwersytetach do badania opinii studentów na temat zajęć dydaktycznych pojawiają się takie właśnie niedookreślone i niezdefiniowane

3 Zobacz na ten temat uwagi zawarte w pracy Earla Babbiego (2003, s. 273). Respondent musi być w stanie odpowiedzieć na pytania: „prosząc respondentów o to, by udzielili informacji, należy ciągle zadawać sobie pytanie, czy mogą oni uczynić to wiarygodnie” (ibidem). Co więcej, wypełniający kwestionariusz musi być przygotowany do odpowiedzi na pytania, które powinny mieć znamiona obiektywizmu, bez nadużywania określeń obciążonych emocjonalnie - ich użycie może być wszak podstawą do kwestionowania poszczególnych odpowiedzi i wyników całości badania. Jak zakłada Babbie: „sens czyjejś odpowiedzi na dane pytanie zależy w dużej mierze od jego sformułowania. (...) pewne pytania bardziej niż inne zachęcają do udzielenia określonych odpowiedzi. W kontekście układania kwestionariusza pojęcie obciążenia (bias) odnosi się do każdej własności pytań, która nakłania respondentów do odpowiadania w określony sposób” (ibidem, s. 275).

Na ten temat zob. również uwagi Howarda Schumana (2013, s. 118 i nast.) - sondaże uzupełniane są o wymiar interpretacyjny, co oznacza, że badacz powinien zastanawiać się nie tylko nad odpowiedzią na podstawowe pytanie „dlaczego?”, ale także uwzględniać przy tym kwestie dotyczące języka, uwarunkowania kontekstowe, cechy społeczno-demograficzne badanego oraz całą złożoną kwestię przyczynowości w badaniu. Wszystkie one tworzą dodatkowe wymiary obciążające proces badania i interpretowania jego wyników. 
w kwestionariuszach kategorie, które wymykają się interpretacjom wspólnym dla wszystkich (w kategoriach lintonowskich uniwersaliów) - układający pytania przyjęli za pewnik taką właśnie jednoznaczną interpretację, jednak wziąwszy pod uwagę różnorodność środowisk, z których pochodzą studenci, możemy uznać, że popełniono tu błąd, przyjmując, że dana kategoria będzie rozumiana jednoznacznie przez respondentów. Zacytujmy kilka pytań z kwestionariuszy pochodzących z różnych polskich uczelni, w których użyto określeń nie do końca dających się interpretować w jednoznaczny sposób (autor artykułu wyszczególnił w pytaniach te sformułowania, które są przedmiotem niniejszej uwagi krytycznej):

Czy zajęcia były prowadzone w sposób interesujący?

Czy prowadzący umiejętnie wiązał teorię z praktyką?

Czy zależałoby Ci na tym, by intensywność nauki na Twoim kierunku była większa niż obecnie?

Jak oceniasz poziom zaangażowania prowadzącego w wyjaśnianie omawianych zagadnień?

Podaj charakter wykładu z ocenianego przedmiotu.

Czy uważa Pan/i oceniany przedmiot za wartościowy dla kierunku studiów?

Interpretacja określeń użytych w podanych powyżej przykładowych pytaniach wynika na ogół z bagażu klasowego i doświadczeń kulturowych odpowiadających na pytania - a ten może być wszak bardzo różnorodny. Wydaje się zatem, że nie możemy mówić zatem o jednolitej interpretacji pytań, w których użyte zostały te właśnie kategorie, co sprawia, że interpretacja wyników badania musi mieć charakter nie do końca adekwatny.

Przedostatnia kwestia, na którą warto zwrócić uwagę w niniejszym kontekście, to problem, który pojawia się w wszystkich badaniach netnograficznych, a związany ze statusem osoby wypełniającej ankietę. Badacz nigdy nie ma pewności, czy wypełniającym jest ta sama osoba, która jest właścicielem konta w systemie uniwersyteckim. Ankietę można wypełnić wszędzie tam, gdzie zarejestrowana osoba ma dostęp do łączy internetowych, co oznacza, że student może ją wypełnić na uczelni, ale też we własnym domu, stancji, domu akademickim czy w miejscu publicznym (komunikacja miejska, centrum handlowe itp.). Wiąże się to nie tylko z możliwym brakiem skupienia na treściach zwartych w ankiecie, ale też z możliwością wypełnienia kwestionariusza przez osoby niebędące studentami. Można tym samym wyobrazić sobie, że ankietę w USOS wypełnia rodzeństwo zalogowanego studenta (czyniąc z tego formę internetowej rozrywki) lub jego znajomi, nieposiadający statusu studenckiego. Wartość merytoryczna takiego 
badania będzie, z oczywistych powodów, kwestionowalna, jednak zauważmy, że osoby odpowiadające za jakość kształcenia na uczelniach nie mają w tej sytuacji żadnej kontroli nad kontekstem całości badania i nie mają możliwości weryfikacji tożsamości osoby realnie wypełniającej kwestionariusz. Możliwym przezwyciężeniem takiej niedogodności jest wypełnianie ankiet na uczelni w przygotowanej w odpowiednią liczbę stanowisk komputerowych sali.

Wreszcie problem ostatni, który można określić jako fetyszyzacja badań ankietowych. Oznacza to nadmierne zaufanie do tego typu badań w kontekście poznawania opinii studentów o wykładowcach i innych kwestiach dotyczących przebiegu studiów i samego studiowania. Większość uniwersytetów bada studentów jedynie za pomocą ankiety - jej wyniki stanowią podstawę do uogólnień, związanych z jakością kształcenia w poszczególnych placówkach, choć stosowane przez polskie uczelnie regulaminy dopuszczają także inne formy badań studenckich respondentów. Z takim podejściem mamy do czynienia na UMK, UAM, UWM czy UW - oficjalne uczelniane dokumenty dotyczące jakości kształcenia wskazują właśnie ankiety jako jedyny sposób badania zadekretowany przez władze uczelni (nie oznacza to jednak, że poszczególne wydziały nie wprowadzają innych metod służących poznawaniu opinii i postaw studenckich - jak ma to miejsce na UW, UMK czy UAM). Wydaje się, że takie podejście jest błędne i nie może przynieść spodziewanych rezultatów, zwłaszcza że badanie przebiega w specyficznym środowisku. Procedury projakościowe powinny zakładać zastosowanie triangulacji jako zespołu złożonych działań prowadzących do wzmacniania jakości oferty dydaktycznej na państwowych wyższych uczelniach. Ich podstawowym minusem jest fakt, że często wymagają one dodatkowych kosztów oraz nakładów czasu i energii ponoszonych przy planowaniu, przygotowaniu, realizacji, opracowaniu i interpretowaniu badań i zgromadzonych danych.

\subsection{PROCEDURY TRIANGULACYJNE}

W ostatnim punkcie zwrócono uwagę na problem nadmiernej ufności, jaką na polskich uniwersytetach przywiązuje się do badań ankietowych jako najlepszego sposobu wiodącego do poznania opinii studentów o problemach związanych z jakością kształcenia. Założyć można, że studenci - należący zazwyczaj do osób młodych i inteligentnych - są grupą, która chętnie dzieli się spostrzeżeniami na tematy związane z jakością studiowania, programów studiów czy jakością pracy dydaktycznej nauczycieli akademickich. W związku z tym ankieta powinna być jedynie jedną z wielu prób dotarcia do przejawianych przez nich postaw wobec uniwersytetu i jakości studiowania. Innymi słowy, w perspektywie długofalowej 
należy zadbać o odpowiednie procedury triangulacyjne w projakościowych badaniach nad populacją studentów.

Triangulacja, jak zauważa Uwe Flick:

zakłada prowadzenie badań przez kilku badaczy, przyjmujących różne podejścia do badanego zagadnienia lub - szerzej - stosujących różne sposoby odpowiadania na pytania badawcze. Takie podejścia mogą być zakorzenione w różnych metodach i/lub perspektywach teoretycznych. (...) Triangulacja (różnych metod lub rodzajów danych) ma w założeniu doprowadzić do uzyskania istotnej nadwyżki wiedzy (2011, s. 81).

Z kolei Norman Denzin określa cele takiego postępowania badawczego jako uzyskiwanie wyższej jakości w badaniach niż w sytuacji, gdy badacze korzystają tylko z jednej metody gromadzenia i interpretacji danych w konkretnym badaniu:

łącząc w obrębie jednego badania różne metody i perspektywy różnych badaczy, obserwatorzy mogą przynajmniej częściowo przezwyciężyć ułomności badań prowadzonych przez jednego badacza i lub przy użyciu jednej metody. (...) Triangulacja metod, badaczy, teorii i danych pozostaje najsolidniejszą strategią tworzenia teorii (1970, s. 300).

Tym samym Denzin rozróżnił typy triangulacji (triangulację: teorii, badaczy, metod, danych) jako typy procedur badawczych mających na celu podnoszenie jakości badania w kategoriach trafności, rzetelności i adekwatności procedur badawczych.

Oznacza to, że projektowanie procedur triangulacyjnych powinno być niejako założone we wszystkich badaniach - badanie studentów nie odbiega tu zasadniczo od pożądanych metodologicznie wzorców proceduralnych. Warto jednak zastanowić się, jakie typy triangulacji będą w kontekście badania ankietowego online najbardziej właściwe i adekwatne do sytuacji, w której się znaleźliśmy. Wobec wskazanych w artykule problemów, jakie napotkać można w tego rodzaju badaniach, można założyć, że najodpowiedniejsze procedury triangulacyjne to triangulacja teorii i metod. Ta pierwsza zakłada możliwość interpretowania gromadzonych danych z różnych perspektyw teoretycznych, po to, by ujmować je w kategoriach możliwych różnorodnych wyjaśnień danego problemu. Tym samym, jak zauważa Denzin, badacz nie przywiązuje się jedynie do jednej konkretnej perspektywy, lecz szuka wyjaśnień w oparciu o inne - rozważają alternatywne interpretacje problemów. Triangulacja metod jest zdaniem Denzina elastycznym 
łączeniem różnych metod badawczych: „każda z metod ma właściwe sobie mocne i słabe strony. (...) Metody trzeba dobierać, kierując się ich znaczeniem teoretycznym” (ibidem, s. 306). Elastyczność, na którą Denzin zwraca uwagę, ma zapewnić dostosowanie metod i procedur triangulacyjnych do danego badania, często odbywającego się w dynamicznym środowisku, związanym z obserwacją i rejestracją ludzkich działań i zachowań.

W odniesieniu do badania ankietowego online triangulacja przebiegać może jako znalezienie odpowiednich metod i teorii, które w elastyczny sposób uzupełniłyby dane uzyskane na podstawie badania kwestionariuszowego. Warto w tym kontekście zwrócić uwagę na takie metody i techniki badań, jak:

- wywiady swobodne z przedstawicielami grup studenckich;

- wywiady nieformalne w formie rozmów ze studentami;

- wywiady grupowe oraz

- grupy fokusowe.

Co oczywiste, zaproponowana tu procedura triangulacyjna łączyć będzie podejście ilościowe i jakościowe, a wywiady oraz fokusy przeprowadzone musiałyby zostać - z założenia - na grupach osób dobranych za pomocą doboru losowego lub prób typu eksperckiego. W pierwszym przypadku można byłoby mówić o reprezentatywności (przy odpowiednim ustawieniu parametrów próbkowania wielopoziomowej złożonej próby warstwowej), w drugim - o wyselekcjonowaniu osób do badania na podstawie ich cech osobowościowych i charakterologicznych zaobserwowanych podczas zajęć dydaktycznych przez wykładowców. Podstawową zaletą takich badań jest możliwość poznania opinii wyrażanych bezpośrednio przez wybranych respondentów, a więc próba dotarcia do wypowiedzi badanych nieograniczanych przez typ pytań kwestionariusza, kolejnością pytań i ich treścią.

\section{UWAGI KOŃCOWE}

Badania ankietowe prowadzone w środowisku online są często stosowanym sposobem wiodącym do poznania opinii i postaw respondentów. Zaufanie do tej techniki gromadzenia danych bierze się stąd, że kwestionariusze przeprowadzane w środowisku nowych mediów posiadają cechy analogiczne do badań typu tradycyjnego, a przy tym posiadają dodatkowe aspekty, które uznać można za istotne z metodologicznego punktu widzenia. Należą do nich łatwość dotarcia do respondenta, łatwość wypełniania kwestionariusza, nieograniczona dostępność kwestionariusza czy - co szczególnie istotne w badaniach na dużych grupach ludzkich - wyeliminowanie efektu ankietera. 
Zalety te można wykorzystać z powodzeniem podczas badań ankietowych online na polskich uczelniach wyższych. Kwestionariusze są wykorzystywane przez większość krajowych uniwersytetów jako stały element ewaluacji jakości kształcenia. Badamy przy ich pomocy postawy i opinie studentów dotyczące jakości pracy dydaktycznej, treści programów nauczania, czy też postaw wykładowców wobec uczących się. Dodać jednak wypada, że badanie typu sondażowego stosowane jako jedyna procedura ewaluacyjna może okazać się niewystarczające. Warto tym samym sukcesywnie uzupełniać wyniki takiego badania o dane pozyskiwane za pomocą innych metod. Innymi słowy, konieczne jest stosowanie procedur triangulacyjnych przez instytucje edukacyjne w celu podnoszenia jakości kształcenia na polskich uniwersytetach.

\section{Literatura:}

Babbie, E. (2003). Badania społeczne w praktyce. Warszawa: PWN.

Denzin, N. (1970). The Research Act. Chicago: Aldine Pub. Co.

Flick, U. (2011). Jakość w badaniach jakościowych. Warszawa: PWN.

Kozinets, R. (2012). Netnografia. Badania etnograficzne online. Warszawa: PWN.

Lutyńska, K. (1993). Surveye w Polsce. Warszawa: IFiS PAN.

Lutyńska, K. (2000). Metodologia badań socjologicznych. Warszawa: PWN.

Nowak, S. (1985). Metodologia badań społecznych. Warszawa: PWN.

Schuman, H. (2013). Metoda i znaczenie w badaniach sondażowych. Warszawa: PWN.

Sobieszek, K., Problem błędu braku odpowiedzi w badaniach internetowych - rozważania teoretyczne. W: Ł. Jonak, P. Mazurek, M. Olcoń i in. (red.), Re: internet - społeczne aspekty medium. Polskie konteksty i interpretacje (s. 365-394). Warszawa: Wydawnictwa Akademickie i profesjonalne.

Sułek, A. (1990). W terenie, w archiwum, w laboratorium. Warszawa: Inst. Socjologii UW. Sułek, A. (2002). Ogród metodologii socjologicznej. Warszawa: Scholar.

Szpunar, M. (2008). Jak zwiększać odsetek wypełnień w badaniu internetowym - fakty i mity na temat kwestionariuszy on-line. Studia Medioznawcze, 1, s. 42-54.

Szreder, M. (2010). Metody i techniki sondażowych badań opinii. Warszawa: PWE.

Sztumski, J. (1995). Wstęp do metod i technik badań społecznych. Katowice: Wydawnictwo Śląsk.

Zając, J.M. (2006). Nieważne jak pytasz: cechy zaproszenia a skłonność do udziału w ankiecie internetowej. W: M. Sokołowski (red.), Oblicza Internetu. Internet w przestrzeni komunikacyjnej XXI wieku (s. 167-178). Elbląg: Wydawnictwo PWSZ.

Zając, J.M., Batorski, D. (2007). Jak skłonić do udziału w badaniach internetowych: zwiększanie realizacji próby. Psychologia Społeczna, 3-4 (5), s. 234-247. 